\title{
Experimental Investigation and Process Optimization of Biodiesel Production from Kusum Oil Using Taguchi Method
}

\author{
Rabiranjan Murmu ${ }^{1,2}$, Harekrushna Sutar ${ }^{1 *}$, Sangram Patra ${ }^{1}$ \\ ${ }^{1}$ Chemical Engineering Department, Indira Gandhi Institute of Technology, Sarang, India. \\ ${ }^{2}$ Chemical Engineering Department, Indian Institute of Technology, Madras, India \\ Email: ${ }^{\star h}$.k.sutar@gmail.com
}

How to cite this paper: Murmu, R., Sutar, H. and Patra, S. (2017) Experimental Investigation and Process Optimization of Biodiesel Production from Kusum Oil Using Taguchi Method. Advances in Chemical Engineering and Science, 7, 464-476.

https://doi.org/10.4236/aces.2017.74033

Received: September 19, 2017

Accepted: October 28, 2017

Published: October 31, 2017

Copyright ( $) 2017$ by authors and Scientific Research Publishing Inc. This work is licensed under the Creative Commons Attribution International License (CC BY 4.0).

http://creativecommons.org/licenses/by/4.0/

\begin{abstract}
The paper focuses on biodiesel production from kusum oil using esterification reaction followed by transesterification reaction in an in-house batch reactor setup. The effects of methanol to oil ratio (M/O), catalyst amount $\left(\mathrm{H}_{2} \mathrm{SO}_{4}\right.$ and methodoxide) and reaction temperature on acid value and fatty acid methyl esters (FAME) is studied. Product has been analysed using FTIR spectroscopy technique for confirmation of ester group in biodiesel. Experimental data was optimized by Taguchi analysis to conclude the optimum variable affecting the response. In both processes $\mathrm{M} / \mathrm{O}$ ratio has the significant effect for biodiesel production. The obtained biodiesel properties are close to commercial diesel fuel and may be rated as an alternative to conventional diesel. The biodiesel production will enhance the maximum utilisation of forestry or agricultural products.
\end{abstract}

\section{Keywords}

Kusum Oil, Biodiesel, Esterification, Transesterification, Taguchi Technique, Analysis of Variance

\section{Introduction}

All over the world demand of fuel is increasing because of the limited availability of fossil fuel resource and its increased usage. In the recent year net energy demand is expected to rise up to $4.8 \%$ per year. Increased consumption of fuels has an adverse effect to the environment. The limited availability of petroleum reserves and the negative effects of exhaust gases from petro and petro derived products have forced us to search for new alternative sources. Various alterna- 
tive fuels like biogas, producer gas, ethanol, methanol and biodiesel are considered [1]. Nowadays biodiesel is chosen as a potential fuel because of its less polluting nature than the conventional diesel [2]. Many researchers work dedicatedly to use vegetable oil derived fuels in existing diesel engines. But use of raw vegetable oils is restricted in diesel engine due to their unfavorable physical properties, particularly their viscosity [3]. Due to higher viscosity of the vegetable oil it causes poor fuel atomization, incomplete combustion, carbon deposition and dilution of lubricating oil on the internal combustion engine [4]. Important methods by which oil and fats are converted to biodiesel are pyrolysis, blending, micro-emulsions and transesterification [5]. The best method by which fatty acid of crude vegetable oil is converted to its ester is known as transesterification [6]. Biodiesel has similar properties to that of diesel produced from crude oil. It is biodegradable, can be used in existing engines without modifying and it produces less harmful gas like sulphur dioxide [7] [8] [9]. But use of edible oil as a raw material for the production of biodiesel is not survived on global fuel market because of its high price. The most important alternative resource for biodiesel production is non-edible oil which is not used for human consumption and could get bulk quantity by means of agricultural or forestry product. Non-edible oils are unsuitable for human consumption because of the presence of toxic compounds. Non-edible resource has the potential to replace conventional edible resource for biodiesel production [10]. However most of the non-edible oils have high free fatty acid (FFAs) contents, which increase the cost of biodiesel production [11].

The botanical name of kusum is Schleichera oleosa and it appears greenish, larger to medium sized and 35 to $55 \mathrm{ft}$ in height [12]. Its growth mainly occurs in sub Himalayan tracts in the north, central parts of eastern India. The flowers come from February to April and yields fruit in June and July. The Seeds are round in shape with $1.5 \mathrm{~cm}$ in diameter and weighing between 0.5 and $1.0 \mathrm{~g}$. The weight of 1000 seeds is $500-700 \mathrm{~g}$. The fruits are berry, globose or ovoid, and hard skinned berry with a pointed tip and Size is $(1.25-2.5) \times(1.1-1.8) \mathrm{cm}$; one cell contains 1 or 2 irregularly ellipsoidal slightly compressed seeds with a thick brown seed coat. The seeds are brown, irregularly elliptic, slightly compressed, oily, enclosed in a succulent aril. The brown seed coat is brittle and breaks at a slight pressure to expose a " $U$ " shape kernel [13] [14]. Kusum oil is extracted from the kernel of kusum seed. The fatty acid profile suggests that it has $40 \%$ unsaturated fatty acids and $53 \%$ saturated fatty acids. Because of the high degree of saturation it has better oxidative stability. Because of the presence of less free fatty acid content, kusum oil has a potential to use feedstock for biodiesel production. Constant effort should be made by all stake holders for large scale cultivation of kusum tree in India and for production of biodiesel a competitive price [15].

Different experiments are carried out to optimize the pretreatment process for reducing the free fatty acid (FFA) content of kusum oil below $1 \%$ for maximum 
biodiesel production. The work focuses on the reaction parameters that affect conversion of FFAs from raw kusum oil and fatty acid methyl easter (FAME) yield in transesterification process. In pretreatment process, reaction between oil and methanol was carried out with the presence of acid catalyst. For transesterification process a base catalyst is used. The main objective was to analyze the experimental data in Minitab-14 to understand the relationships between the variables (methanol-to-oil ratio, catalyst concentration and reaction time) and the response (acid value after pretreatment and FAME yield).

\section{Materials and Methods}

Kusum oil is obtained from the kernel of kusum tree (Schleichera oleosa), which is collected from Mayurbhanj district, Odisha. The unrefined but filtered crude kusum oil is greenish yellow in colour. Fatty acid profile of kusum oil is given in Table 1 . The fatty acid profile tests are conducted as per the conventional methods in our laboratory. Its FFA content was determined by a standard titrimetry method [16]. This oil had an initial acid value of $13 \mathrm{mg} \mathrm{KOH} / \mathrm{g}$ corresponding to a FFA level of $8 \%$, which is far above the $1 \%$ limit for satisfactory transesterification reaction using alkaline catalyst. Because of its less free acid content, it was preferred more compared with other vegetable oil. Therefore, FFAs were first converted to esters in a two-step pretreatment process using an acid catalyst $\left(\mathrm{H}_{2} \mathrm{SO}_{4} 4 \% \mathrm{v} / \mathrm{v}\right)$ to reduce the acid value of kusum oil below $2 \mathrm{mg} \mathrm{KOH} / \mathrm{g}$. Experiments were conducted in a laboratory-scale setup.

\subsection{Experimental Set up}

Biodiesel production was carried out in a custom built esterification set up shown in Figure 1. It consists of a batch reactor supported with iron stand. Oil

Table 1. Fatty acid profile of kusum oil and properties comparison.

\begin{tabular}{|c|c|c|c|c|c|c|}
\hline \multicolumn{3}{|c|}{ FATTY ACID PROFILE OF KUSUM OIL } & \multicolumn{4}{|c|}{ PROPERTIES COMPARISION } \\
\hline Sl. No. & Fatty Acid & Percent & Properties Measured & $\begin{array}{c}\text { Kusum } \\
\text { Oil }\end{array}$ & Biodiesel & Diese \\
\hline 1 & Myristic acid (C14:0) & 0.01 & Flash Point $\left({ }^{\circ} \mathrm{C}\right)$ & 268 & 70 & 68 \\
\hline 2 & Palmitic acid (C16:0) & 7.59 & Fire Point $\left({ }^{\circ} \mathrm{C}\right)$ & 275 & 75 & 73 \\
\hline 3 & $\begin{array}{c}n-7 \text { Palmitic oleic acid } \\
(\mathrm{C} 16: 1)\end{array}$ & 1.80 & $\begin{array}{c}\text { Viscosity } \\
\text { (redwood second) }\end{array}$ & 121 & 71 & 67 \\
\hline 4 & $\begin{array}{c}n-9 \text { cis Oleic acid } \\
(\mathrm{C} 18: 1)\end{array}$ & 2.83 & Pour Point $\left({ }^{\circ} \mathrm{C}\right)$ & 12 & -4 & -6 \\
\hline 5 & $\begin{array}{c}\mathrm{n}-6 \text { Translinoleic acid } \\
(\mathrm{C} 18: 2)\end{array}$ & 49.69 & $\begin{array}{l}\text { Acid Value } \\
(\mathrm{Mg} \mathrm{KOH} / \mathrm{g})\end{array}$ & 13 & 0.46 & 0.35 \\
\hline 6 & $\begin{array}{c}n-3 \text { alpha-linoleic acid } \\
\text { (C18:3) }\end{array}$ & 0.26 & Calorific Value (MJ/kg) & 38 & 42 & 45 \\
\hline 7 & $\begin{array}{c}n-9 \text { Eicosenoic acid } \\
(C 20: 1)\end{array}$ & 29.54 & Carbon Residue (\%) & 0.42 & 0.36 & 0.30 \\
\hline
\end{tabular}




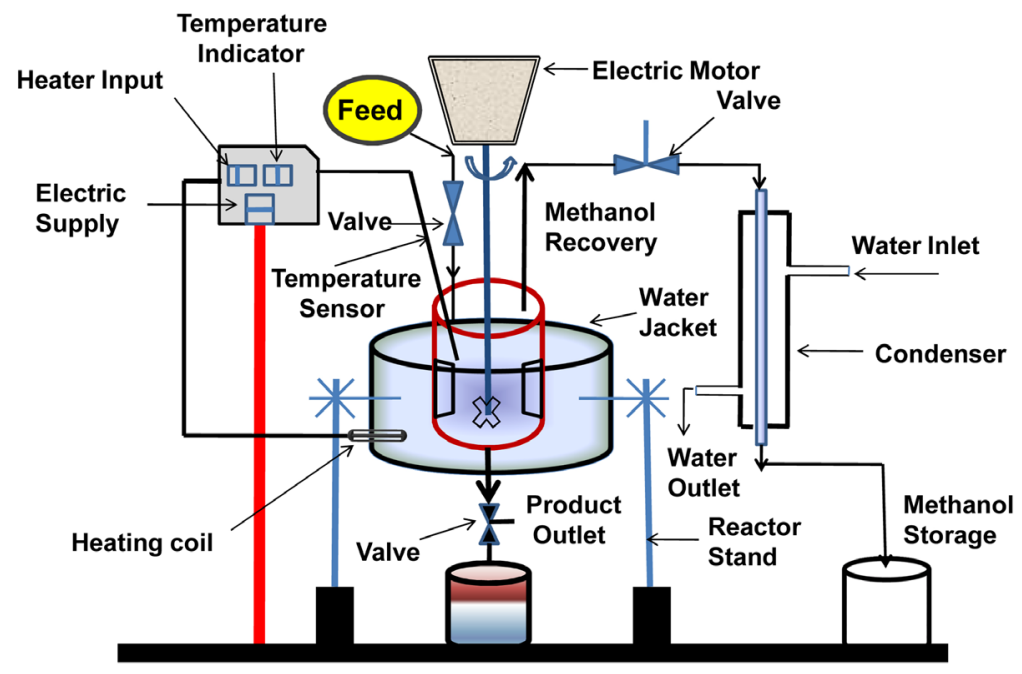

Figure 1. Experimental set up for biodiesel production.

sample, ethanol and catalyst is fed to the inlet of reactor. To maintain the desired temperature of the reactant sample, water filled jacketed vessel was used. Heating of the water in a jacketed vessel was done by electric heater. For perfect mixing of fluid in a reactor, agitator is rotated in a constant speed of $600 \mathrm{rpm}$. Temperature of the reactant sample can be checked by temperature sensor on a continuous interval of time. To enhance the rate of mixing of reactant mixture baffle ware fitted in the reactor. Product sample ware collected on bottom of the reactor. The volatile product (methanol) is collected on the top of reactor outlet. Then it was sent to methanol recovery tower consisting of a vertical condenser. The methanol was collected from the condenser and it can be stored. The bottom product of the batch reactor consists of FAME and glycerol. It makes of two immiscible layers and can be separated based on their density difference. The bottom layer consists of glycerol and top layer was biodiesel (FAME). Then the biodiesel (FAME) was be separated and washed with distilled water for several times to get pure biodiesel (FAME). Glycerol is more valuable than biodiesel, which can be stored.

\subsection{Pretreatment}

The pretreatment process comprised of two steps. In each step, different methanol-to-oil ratios $(\mathrm{v} / \mathrm{v})(0.25,0.33$, and 0.40$)$ and reaction temperature $\left(55^{\circ} \mathrm{C}\right.$, $67^{\circ} \mathrm{C}, 75^{\circ} \mathrm{C}$ ) were used to investigate their influence on the acid value of crude kusum oil. After the reaction, the mixture was allowed to settle for $1 \mathrm{~h}$ and the methanol-water fraction that separated at the top was removed in a separating funnel. The acid value of the product separated at the bottom was determined. The effect of methanol-to-oil ratio, reaction temperature and catalyst concentration on reduction of acid value of this raw material was studied. The final product having acid value less than $2 \mathrm{mg} \mathrm{KOH} / \mathrm{g}$ can be used as a raw material for transesterification process. A set of 27 experiment were carried out by taking different combination methanol-to-oil ratio, catalyst concentration and reaction temperature. All the reaction was performed at a constant reaction time of 1 
hour. In pretreatment process two important things was observed. When acid catalyst concentration exceed more than $4 \%$ product appear black. Simultaneously esterification and transesterification reaction will be carried out and some amount of FAME produced.

\subsection{Transesterification}

The transesterification reaction was carried out with different methanol-to-oil ratios (v/v) $(0.25,0.30 .0 .35)$, Methoxide as an alkaline catalyst w/v $(5,7,9)$ and reaction temperature $\left(55^{\circ} \mathrm{C}, 65^{\circ} \mathrm{C}, 75^{\circ} \mathrm{C}\right)$. The reaction was carried out at $65^{\circ} \mathrm{C}$ for half an hour. Again the effect of methanol-to-oil, reaction temperature and catalyst concentration on production of FAME yield can be studied by statistical method. Biodiesel can be separated from the two phase glycerol-FAME (Biodiesel) mixture. The fuel properties namely, density, kinematic viscosity, flash point, pour point, water content, ash content, carbon residue, acid value and calorific value of kusum oil, kusum biodiesel and conventional diesel were determined as per the standards prescribed by ASTM for comparison with the latest American and European standards [16] [17].

\section{Statistical Analysis}

\subsection{Design of Experiments (DOE)}

Design of Experiments (DOE) is one of the important and powerful statistical techniques to study the effect of multiple variables simultaneously and involves a series of steps which must follow a certain sequence of experiment to yield an improved understanding of process performance as reported by Taguchi G (1990). In the present work Taguchi's parameters design approach is used to study the effect of operating parameters on the acid value and yield of fatty acid methyl ester (FAME).

\subsection{Selection of Orthogonal Array}

Taguchi method which combine the experiment design theory and the quality loss function concept has been used in developing robust design of products in process and in the solving of sum taxing problems of manufacturing. The selection of orthogonal array depends on 3 items in order of priority, viz. The number of factors and their interactions, number of levels for the factors and the desired experimental resolution or cost limitation. In this research 27 experiments were conducted at different parameters. For this Taguchi L27 orthogonal array was used, which has 27 rows corresponding to the number of tests with 3 columns at 3 levels. The layout of L27 orthogonal array is shown in Figure 2.

Experimental design with a L27 orthogonal array as suggested by Taguchi has been used to carry experiments with 3 input parameters and for 3 levels of individual parameters. Factors and their levels are tabulated in Table 2 and Table 3.

A: Methanol-to-oil ratio, B: Catalyst Concentration (volume \%), C: Reaction Temperature $\left({ }^{\circ} \mathrm{C}\right)$. 


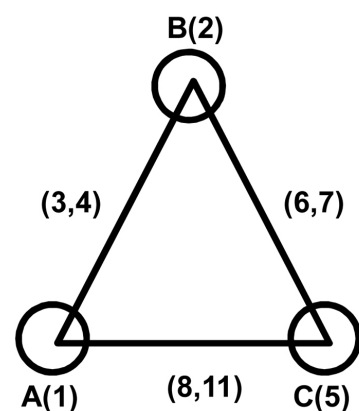

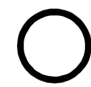

(9)

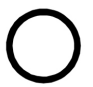

(10)

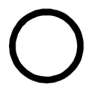

(12)

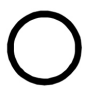

(13)

Figure 2. Layout of orthogonal array.

Table 2. Pretreatment process design.

\begin{tabular}{cccc}
\hline Factors & A & B & C \\
\hline LEVEL 1 & 0.25 & 2 & 55 \\
LEVEL 2 & 0.33 & 4 & 67 \\
LEVEL 3 & 0.40 & 6 & 75 \\
\hline
\end{tabular}

Table 3. Transesterification process design.

\begin{tabular}{cccc}
\hline Factors & A & B & C \\
\hline LEVEL 1 & 0.25 & 5 & 55 \\
LEVEL 2 & 0.30 & 7 & 65 \\
LEVEL 3 & 0.35 & 9 & 75 \\
\hline
\end{tabular}

\section{Results and Analysis of Experiment}

\subsection{Product Characterization}

The biodiesel produced was undergone a FTIR spectroscopy analysis. Absorption peaks are listed in Table 4 and strong peaks (1742.77, 2855.44, 2905.16 and $3000.32 \mathrm{~cm}^{-1}$ ) are shown in Figure 3.

\subsection{Taguchi Treatment Process}

The L27-OA and response values for acid value and FAME yield are shown in Table 5 and Table 6. From the response Table 7 for signal to noise ratio, it was found that methanol-to-oil ratio has the highest influence on acid value followed by catalyst concentration and reaction temperature. From the response Table 8 for signal to noise ratio, it was found that methanol-to-oil ratio has the highest influence on FAME yield followed by catalyst concentration and reaction temperature.

From graph (Figure 4(a)), it was observed that the acid value was highest at $0.25 \mathrm{M} / \mathrm{O}$ ratio and drastically decreased at $0.33 \mathrm{M} / \mathrm{O}$ ratio. The acid value further increased with increase in methanol-to-oil concentration but the extent of rise was lesser compared to the rise observed between $0.25-0.33 \mathrm{M} / \mathrm{O}$ ratio. The FAME yield was at its highest point at 0.33 (Figure 5), then it is slightly 


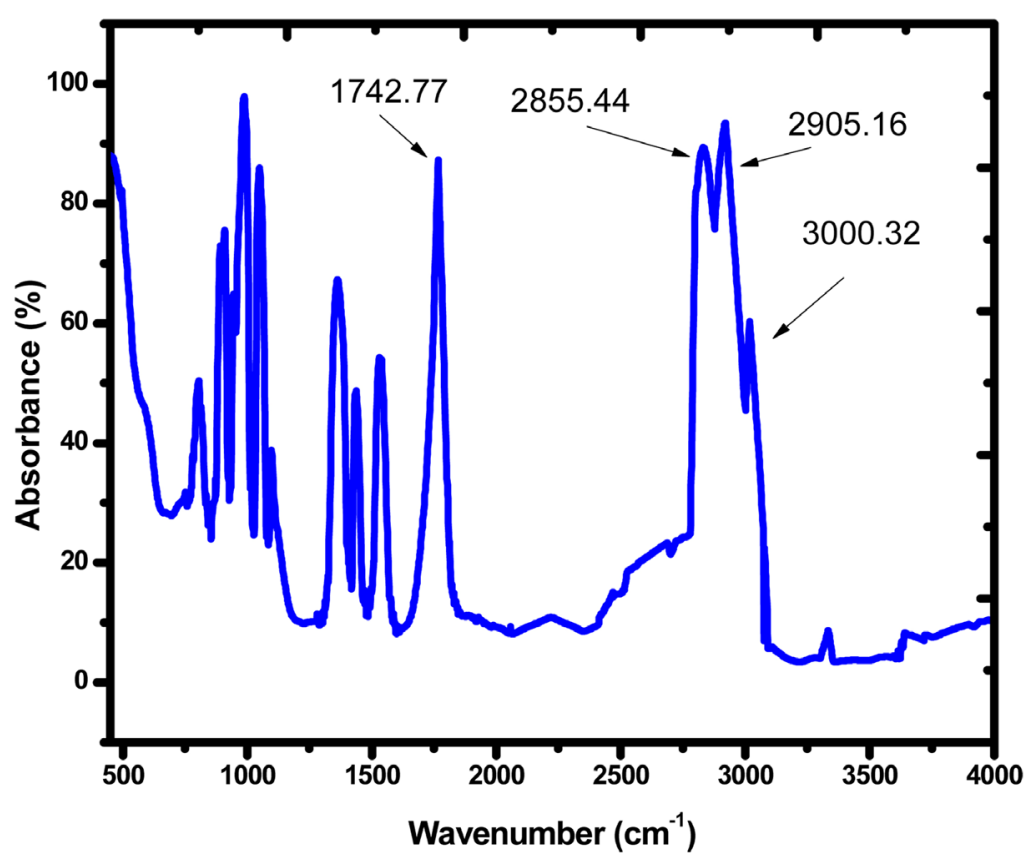

Figure 3. FT-IR Spectroscopy of produced biodiesel.

Table 4. Absorption peaks of biodiesel.

\begin{tabular}{cc}
\hline Wavenumber, $\mathrm{cm}^{-1}$ & Assigned group \\
\hline 3310.23 & $-\mathrm{OH}$ \\
3000.32 & $=\mathrm{C}-\mathrm{H}$ \\
2905.16 & $-\mathrm{CH}_{2}$ \\
2855.44 & $-\mathrm{CH}_{2}$ \\
1742.77 & $-\mathrm{C}=\mathrm{O}$ \\
1461.63 & $-\mathrm{CH}_{2}$ \\
1350.18 & $-\mathrm{CH} 3$ \\
1180.41 & $-\mathrm{C}-\mathrm{O}-\mathrm{C}$ \\
1017.63 & $-\mathrm{C}-\mathrm{O}-\mathrm{C}$ \\
722.85 & $-\mathrm{CH}$ \\
\hline
\end{tabular}

decreased and remains constant for further increase in methanol-to-oil ratio. It was observed that the yield of FAME increased from 0.25 to 0.33 . However, the FAME yield was at its lowest value at $0.25 \mathrm{M} / \mathrm{O}$ ratio.

It was observed that acid value was decreased from 2 to 4 , and then it was increased. The FAME yield was increased from 5 to 7 , and then the FAME yield was drastically decreased for further increase in catalyst (B) concentration.

It is observed that there was marginal decrease in acid value with increase in reaction temperature up to $67^{\circ} \mathrm{C}$ and the acid value was highest at $55^{\circ} \mathrm{C}$. Then the acid value was slightly increased with further increase in reaction temperature. However, the increase in temperature after $65^{\circ} \mathrm{C}$ has no significant effect on FAME yield. 
Table 5. $\mathrm{L}_{27}-\mathrm{OA}$ response values and $\mathrm{S} / \mathrm{N}$ ratio for acid value.

\begin{tabular}{|c|c|c|c|c|c|}
\hline SL NO & $\begin{array}{c}\text { Methanol-to-Oil } \\
\text { Ratio }\end{array}$ & $\begin{array}{c}\text { Catalyst } \\
\text { Concentration }\end{array}$ & Temperature & Acid Value & S/N Ratio \\
\hline 1 & 0.25 & 2 & 55 & 5.20 & 14.3201 \\
\hline 2 & 0.25 & 2 & 67 & 4.01 & 12.0629 \\
\hline 3 & 0.25 & 2 & 75 & 4.03 & 12.1061 \\
\hline 4 & 0.25 & 4 & 55 & 5.10 & 14.1514 \\
\hline 5 & 0.25 & 4 & 67 & 3.98 & 11.9977 \\
\hline 6 & 0.25 & 4 & 75 & 4.01 & 12.0629 \\
\hline 7 & 0.25 & 6 & 55 & 6.20 & 15.8478 \\
\hline 8 & 0.25 & 6 & 67 & 5.80 & 15.2686 \\
\hline 9 & 0.25 & 6 & 75 & 4.96 & 13.9096 \\
\hline 10 & 0.33 & 2 & 55 & 3.21 & 10.1301 \\
\hline 11 & 0.33 & 2 & 67 & 2.96 & 9.4258 \\
\hline 12 & 0.33 & 2 & 75 & 3.30 & 10.3703 \\
\hline 13 & 0.33 & 4 & 55 & 2.10 & 6.4444 \\
\hline 14 & 0.33 & 4 & 67 & 1.03 & 0.2567 \\
\hline 15 & 0.33 & 4 & 75 & 2.20 & 6.8485 \\
\hline 16 & 0.33 & 6 & 55 & 3.90 & 11.8213 \\
\hline 17 & 0.33 & 6 & 67 & 2.90 & 9.2480 \\
\hline 18 & 0.33 & 6 & 75 & 3.12 & 9.8831 \\
\hline 19 & 0.40 & 2 & 55 & 4.56 & 13.1793 \\
\hline 20 & 0.40 & 2 & 67 & 5.67 & 15.0717 \\
\hline 21 & 0.40 & 2 & 75 & 6.10 & 15.7066 \\
\hline 22 & 0.40 & 4 & 55 & 3.68 & 11.3170 \\
\hline 23 & 0.40 & 4 & 67 & 3.21 & 10.1301 \\
\hline 24 & 0.40 & 4 & 75 & 3.43 & 10.7059 \\
\hline 25 & 0.40 & 6 & 55 & 4.97 & 13.9271 \\
\hline 26 & 0.40 & 6 & 67 & 4.73 & 13.4972 \\
\hline 27 & 0.40 & 6 & 75 & 5.20 & 14.3201 \\
\hline
\end{tabular}

\subsection{Analysis of Variance (ANOVA)}

From the Table 9, it was observed that the major controlling parameter for acid value was methanol-to-oil ratio followed by catalyst concentration and interaction parameter $\left(A^{\star} B\right)$. Hence methanol-to-oil ratio was the major process parameter to be considered in this process due its significance influence.

The interaction graphs are shown in the above figure. It is observed from the Figure 6 that the interaction between $A{ }^{\star} B$ shows highest significant effect on acid value. Although the factor B individually has relatively less contribution on 
Table 6. $\mathrm{L}_{27}$-OA response values and $\mathrm{S} / \mathrm{N}$ ratio for FAME yield.

\begin{tabular}{|c|c|c|c|c|c|}
\hline SL NO & $\begin{array}{c}\text { Methanol-to-Oil } \\
\text { Ratio }\end{array}$ & $\begin{array}{c}\text { Catalyst } \\
\text { Concentration }\end{array}$ & Temperature & FAME Yield (\%) & S/N Ratio \\
\hline 1 & 0.25 & 5 & 55 & 53 & 34.4855 \\
\hline 2 & 0.25 & 5 & 65 & 59 & 35.4170 \\
\hline 3 & 0.25 & 5 & 75 & 64 & 36.1236 \\
\hline 4 & 0.25 & 7 & 55 & 68 & 36.6502 \\
\hline 5 & 0.25 & 7 & 65 & 72 & 37.1466 \\
\hline 6 & 0.25 & 7 & 75 & 73 & 37.2665 \\
\hline 7 & 0.25 & 9 & 55 & 56 & 34.9638 \\
\hline 8 & 0.25 & 9 & 65 & 62 & 35.8478 \\
\hline 9 & 0.25 & 9 & 75 & 66 & 36.3909 \\
\hline 10 & 0.30 & 5 & 55 & 73 & 37.2665 \\
\hline 11 & 0.30 & 5 & 65 & 76 & 37.6163 \\
\hline 12 & 0.30 & 5 & 75 & 79 & 37.9525 \\
\hline 13 & 0.30 & 7 & 55 & 84 & 38.4856 \\
\hline 14 & 0.30 & 7 & 65 & 94 & 39.4626 \\
\hline 15 & 0.30 & 7 & 75 & 88 & 38.8897 \\
\hline 16 & 0.30 & 9 & 55 & 79 & 37.9525 \\
\hline 17 & 0.30 & 9 & 65 & 76 & 37.6163 \\
\hline 18 & 0.30 & 9 & 75 & 68 & 36.6502 \\
\hline 19 & 0.35 & 5 & 55 & 73 & 37.2665 \\
\hline 20 & 0.35 & 5 & 65 & 86 & 38.6900 \\
\hline 21 & 0.35 & 5 & 75 & 87 & 38.7904 \\
\hline 22 & 0.35 & 7 & 55 & 78 & 37.8419 \\
\hline 23 & 0.35 & 7 & 65 & 84 & 38.4856 \\
\hline 24 & 0.35 & 7 & 75 & 87 & 38.7904 \\
\hline 25 & 0.35 & 9 & 55 & 68 & 36.6502 \\
\hline 26 & 0.35 & 9 & 65 & 74 & 37.3846 \\
\hline 27 & 0.35 & 9 & 75 & 76 & 37.6163 \\
\hline
\end{tabular}

Table 7. Response table of $\mathrm{S} / \mathrm{N}$ ratio for acid value.

\begin{tabular}{cccc}
\hline Level & A & B & C \\
\hline 1 & 13.525 & 12.486 & 12.349 \\
2 & 8.270 & 9.324 & 10.773 \\
3 & 13.095 & 13.080 & 11.768 \\
Delta & 5.255 & 3.756 & 1.576 \\
Rank & 1 & 2 & 3 \\
\hline
\end{tabular}


Table 8. Response table of S/N ratio for FAME yield.

\begin{tabular}{cccc}
\hline Level & A & B & C \\
\hline 1 & 36.03 & 37.07 & 36.84 \\
2 & 37.99 & 38.11 & 37.52 \\
3 & 37.95 & 36.79 & 37.61 \\
Delta & 1.96 & 1.33 & 0.77 \\
Rank & 1 & 2 & 3 \\
\hline
\end{tabular}

Table 9. ANOVA table for acid value.

\begin{tabular}{cccccccc}
\hline Source & DF & Seq SS & Adj SS & Adj MS & F & P & $\% P$ \\
\hline $\mathrm{A}$ & 2 & 23.3749 & 23.3749 & 11.6874 & 84.51 & 0.000 & 54.48479 \\
$\mathrm{~B}$ & 2 & 10.5052 & 10.5052 & 5.2526 & 37.98 & 0.000 & 24.48668 \\
$\mathrm{C}$ & 2 & 1.1958 & 1.1958 & 0.5979 & 4.32 & 0.053 & 2.787302 \\
$\mathrm{~A}^{\star} \mathrm{B}$ & 4 & 3.5381 & 3.5381 & 0.8845 & 6.40 & 0.013 & 8.246993 \\
$\mathrm{~B}^{\star} \mathrm{C}$ & 4 & 0.7476 & 0.7476 & 0.1869 & 1.35 & 0.331 & 1.742588 \\
$\mathrm{C}^{\star} \mathrm{A}$ & 4 & 2.4338 & 2.4338 & 0.6085 & 4.40 & 0.036 & 5.672969 \\
Error & 8 & 1.1063 & 1.1063 & 0.1383 & & & 2.578686 \\
Total & 26 & 42.9017 & & & & & \\
\hline
\end{tabular}

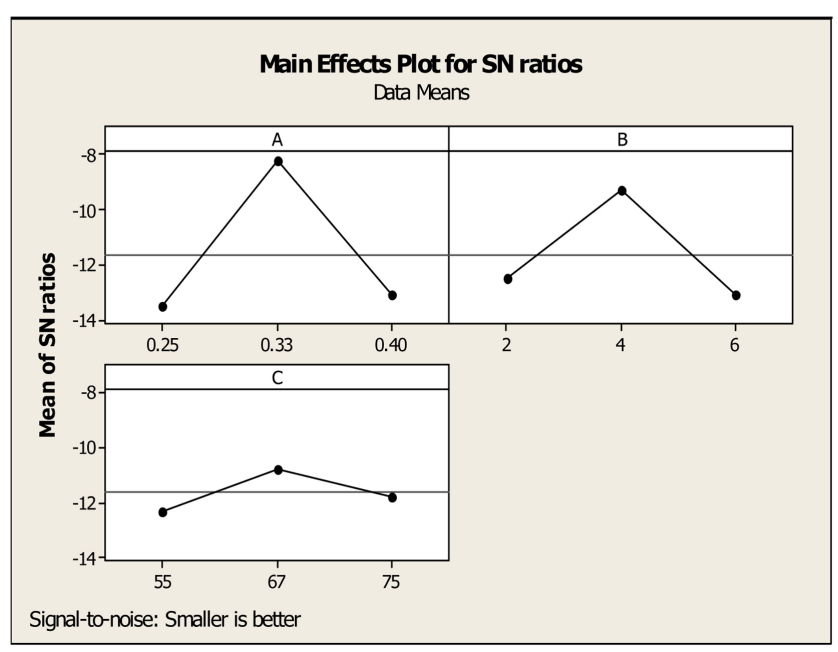

(a)

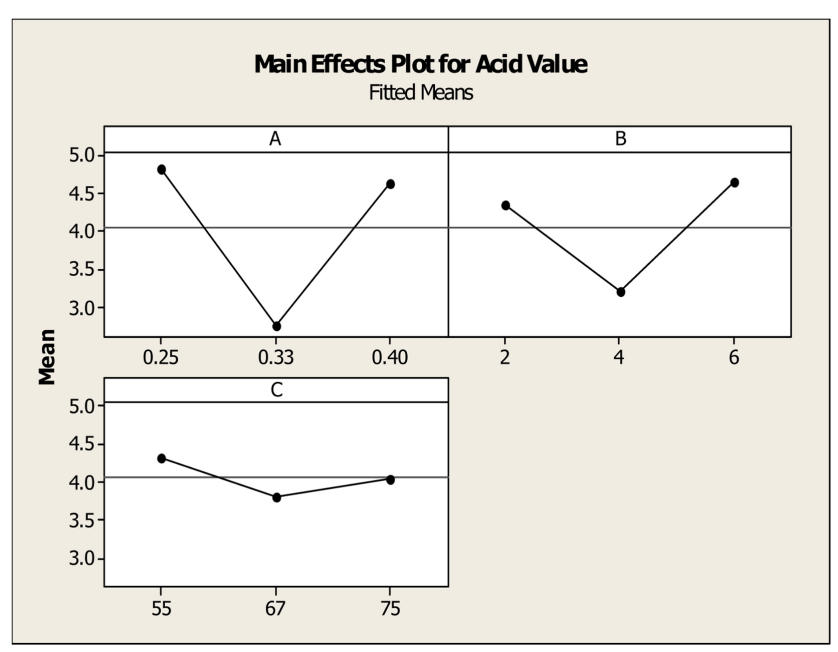

(b)

Figure 4. Main effects plot for (a) SN ratios, (b) data mean for acid value.

output performance, but its interaction with factor A has significant contribution on minimization of acid value. On the other hand the interaction of $\mathrm{B}^{\star} \mathrm{C}$ has least contribution on acid value.

Table 10 shows methanol-to-oil ratio was investigated as the statistically significant parameter having major influence on the response. Catalyst concentration, followed by reaction temperature was the less influencing parameters. 


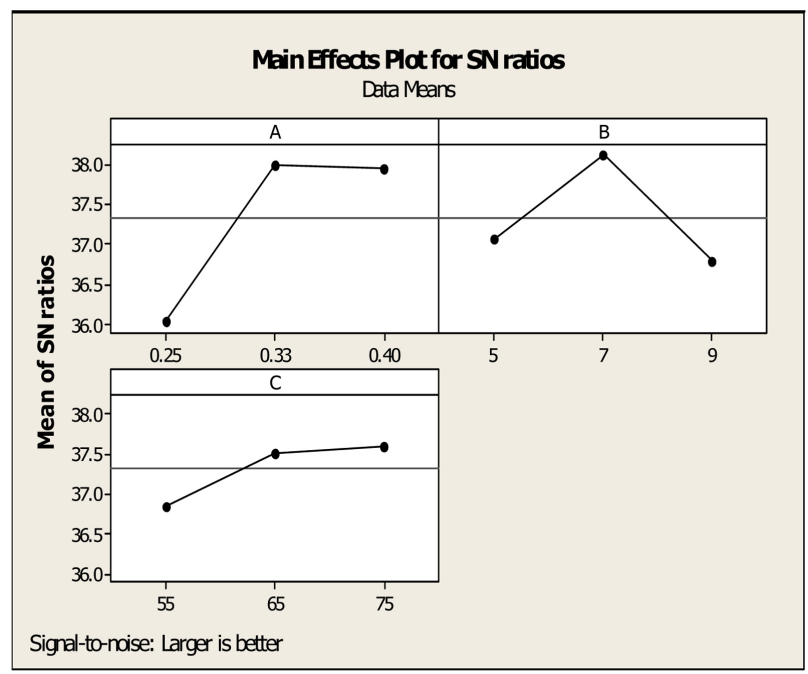

(a)

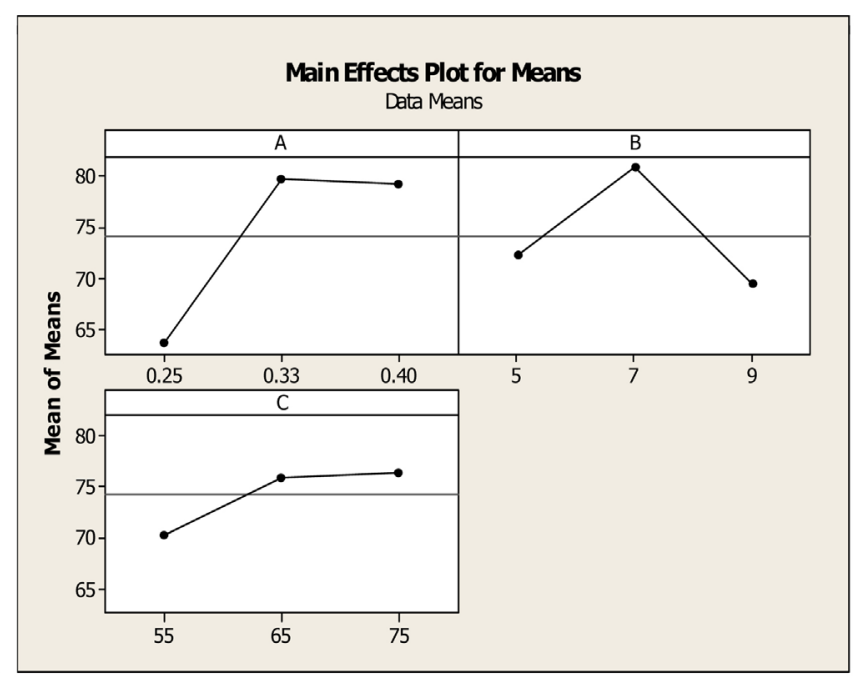

(b)

Figure 5. Main effect plot for (a) SN ratios, (b) data mean for FAME yield.

Table 10. Analysis of variance for FAME yield, using adjusted SS for tests.

\begin{tabular}{cccccccc}
\hline Source & DF & Seq SS & Adj SS & Adj MS & F & P & $\%$ P \\
\hline A & 2 & 1494.52 & 1494.52 & 747.26 & 69.63 & 0.000 & 53.99141 \\
B & 2 & 641.41 & 641.41 & 320.70 & 29.88 & 0.000 & 23.17174 \\
C & 2 & 213.41 & 213.41 & 106.70 & 9.94 & 0.007 & 7.709704 \\
$\mathrm{~A}^{*} \mathrm{~B}$ & 4 & 174.81 & 174.81 & 43.70 & 4.07 & 0.043 & 6.31523 \\
$\mathrm{~B}^{*} \mathrm{C}$ & 4 & 51.98 & 51.98 & 12.98 & 1.21 & 0.378 & 1.877843 \\
$\mathrm{~A}^{*} \mathrm{C}$ & 4 & 106.15 & 106.15 & 26.54 & 2.47 & 0.128 & 3.834802 \\
Error & 8 & 85.85 & 85.85 & 10.73 & & & 3.101439 \\
Total & 26 & 2768.07 & & & & & \\
\hline
\end{tabular}

The interaction graphs are shown in Figure 6(b). It was observed the interaction between $A^{\star} B$ shows major contribution on FAME yield. Although the factor $B$ individually has relatively high significant effect on output performance, but its interaction with factor $\mathrm{C}$ has least contribution on FAME yield.

\section{Conclusion}

Kusum oil is chosen as feedstock because of its high fatty acid and less free fatty acid content. Biodiesel was produced from kusum oil using esterification reaction followed by transesterification reaction in a recently developed esterification setup. Experimental data was optimized by Taguchi analysis. The relationship between response variable and factor were studied by regression analysis. Optimal condition for esterification reaction was methanol-to-oil ratio $(0.33 \mathrm{v} / \mathrm{v})$, sulphuric acid $(4 \% \mathrm{v} / \mathrm{v})$ at $67^{\circ} \mathrm{C}$. From Taguchi analysis, it is found that methanol-to-oil ratio has the maximum effect followed by catalyst concentration and reaction temperature. For transesterification process, optimal value of methanol-to-oil ratio is $0.30 \mathrm{v} / \mathrm{v}$, methodoxide (7\%) and reaction temperature 


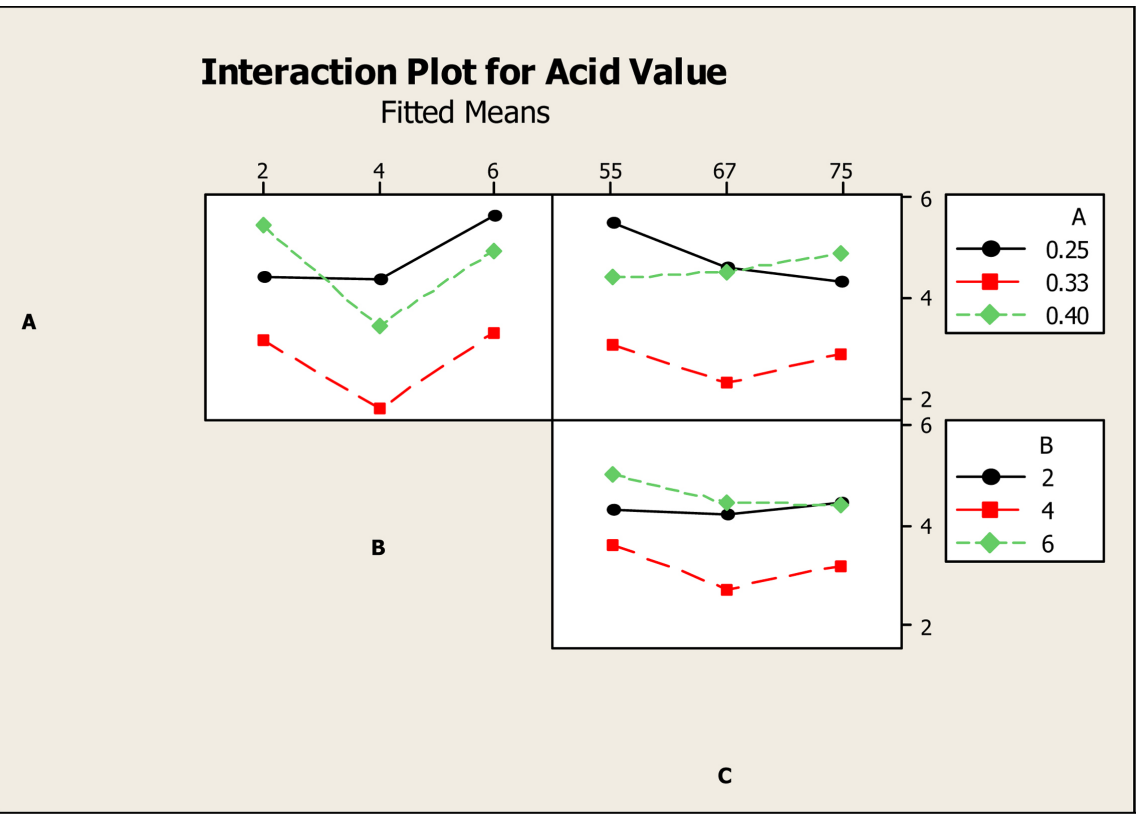

(a)

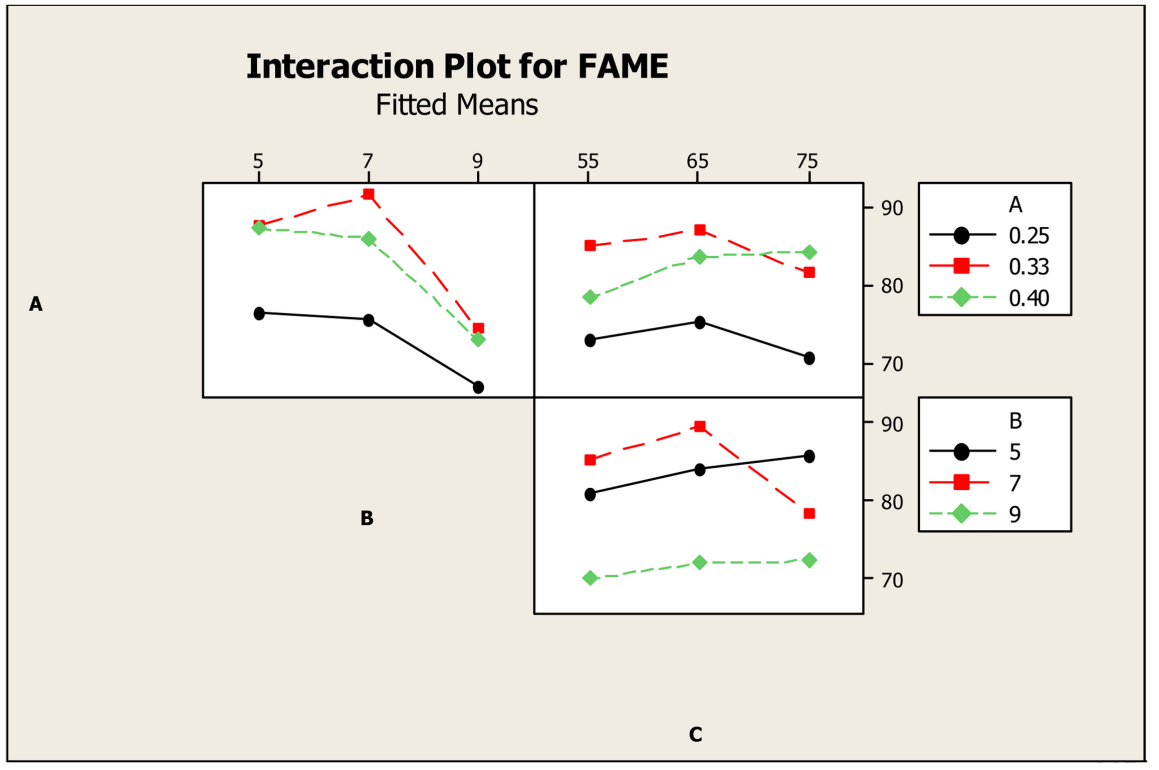

(b)

Figure 6. Interaction plot for (a) Acid value (b) FAME yield.

$\left(75^{\circ} \mathrm{C}\right)$ under proper agitation. This work is a portfolio to future researchers to find out the performance of the produced biodiesel in two stroke engines.

\section{References}

[1] Om, V., Steven, P. and Harvey, S. (2010) Sustainable Biotechnology: Sources of Renewable Energy. Springer, Netherland.

[2] Kaul, S., Kumar, A., Bhatnagar, A.K., Goyal, H.B. and Gupta, A.K. (2003) Biodiesel: A Clean and Sustainable Fuel for Future. Scientific Strategies for Production of Non-Edible Vegetable Oils for Use as Biofuels. All India Seminar on National Policy 
on Non-Edible Oils as Biofuels. IISc, Bangalore.

[3] Bankovic, I.B., Stamenkovic, O.S. and Veljkovic, V.B. (2012) Biodiesel Production from Non-Edible Plant Oils. Renewable and Sustainable Energy Reviews, 16, 3621-3647. https://doi.org/10.1016/j.rser.2012.03.002

[4] Moser, B.R. (2009) Biodiesel Production, Properties, and Feedstocks. In Vitro Cellular \& Developmental Biology-Plant, 45, 229-266.

[5] Srivastava, A. and Prasad, R. (2000) Triglycerides-Based Diesel Fuels. Renewable and Sustainable Energy Reviews, 4, 111-133. https://doi.org/10.1016/S1364-0321(99)00013-1

[6] Ma, F. and Hanna, M.A. (1999) Biodiesel Production: A Review. Bioresource Technology, 70, 1-15. https://doi.org/10.1016/S0960-8524(99)00025-5

[7] Janaun, J. and Ellis, N. (2010) Perspectives on Biodiesel as a Sustainable Fuel. Renewable and Sustainable Energy Reviews, 14, 1312-1320. https://doi.org/10.1016/j.rser.2009.12.011

[8] Gerpen, J.V. (2005) Biodiesel Processing and Production. Fuel Process Technology, 86, 1097-1107. https://doi.org/10.1016/j.fuproc.2004.11.005

[9] Leung Dennis, Y.C., Wu, X. and Leung, M.K.H. (2010) A Review on Biodiesel Production Using Catalyzed Transesterification. Applied Energy, 87, 1083-1095. https://doi.org/10.1016/j.apenergy.2009.10.006

[10] Giakoumis, E.G., Rakopoulos, C.D., Dimaratos, A.M. and Rakopoulos, D.C. (2012) Exhaust Emissions of Diesel Engines Operating under Transient Conditions with Biodiesel Fuel Blends. Progress in Energy and Combustion Science, 38, 691-715. https://doi.org/10.1016/j.pecs.2012.05.002

[11] Leung, D.Y.C., Wu, X. and Leung, M.K.H. (2010) A Review on Biodiesel Production Using Catalyzed Transesterification. Applied Energy, 87, 1083-1095. https://doi.org/10.1016/j.apenergy.2009.10.006

[12] Palanuvej, C. and Vipunngeun, N. (2008) Fatty Acid Constituents of Schleichera oleosa (Lour.) Oken Seed Oil. Journal of Health Research, 22, 203e212.

[13] Acharya, S.K., Mishra, A.K., Rath, M. and Nayak, C. (2011) Performance Analysis of Karanja and Kusum Oils as Alternative Bio-Diesel Fuel in Diesel Engine. International Journal of Agricultural and Bio Engineering, 4, 23.

[14] Sharma, Y.C. and Singh, B. (2010) An Ideal Feedstock, Kusum (Schleichera triguga) for Preparation of Biodiesel: Optimization of Parameters. Fuel, 89, 1470-1474. https://doi.org/10.1016/j.fuel.2009.10.013

[15] Kumar, N. and Pali, H.S. (2013) Kusum Oil as a Potential Fuel for CI Engines. International Conference on Alternative Fuels for I. C. Engines (ICAFICE), Priya Tech Publication Private Ltd, Jaipur, India.

[16] ASTM (2003) American Standards for Testing of Materials. D 189-01, D 240-02, D 4052-96, D 445-03, D 482-74, D 5555-95, D 6751-02, D 93-02a, D 95-990, D 97-02.

[17] European Standard for Biodiesel (2003) EN 14214. 